\title{
An Exploration into Challenges Facing Public Sector Labor Relations: A Literature Review and Analysis
}

\author{
Michael Chambers \\ School of Business and Technology Management, Northcentral University \\ 10000 University Drive, Prescott Valley, AZ 86314
}

Tel: 1-520-508-6213 E-mail: mike_2c@hotmail.com

Accepted: December 28, 2013

doi:10.5296/ jpag.v3i4.4848 URL: http://dx.doi.org/10.5296/ jpag.v3i4.4848

\begin{abstract}
This analysis explores some of the challenges facing public managers in nurturing their relationship and partnership with public-sector unions. It begins with a discussion of the background that elaborates on union history, discussing the birth of unions, the fall of private-sector unions, and the rise of government unions. This is followed by a review of the relevant professional and scientific literature to better develop the topic and focus the analysis. As the field of government labor-management relations is complex, the unique characteristics of government labor-management relationships that are lacking in the private-sector context necessitate a practitioner approach and an integrated synthesis of the literature. The analysis concludes that when collective bargaining is applied to public-sector business, it must be tailored to achieve proper alignment with taxpayers, who are the major stakeholders in public-sector services.
\end{abstract}

Keywords: labor relations, collective bargaining, leadership, human resource management, negotiations, environment, labor law, employee relations 


\section{Introduction}

Since the birth of a worldwide union in 1866, and the enactment of legislation in the 1930s, unions have championed the legislation to improve working conditions, establish the right to organize, and develop appropriate governance of union functions. As non-government union membership weakened, union membership grew in the public sector (Masters, Albright, \& Gibney 2010; Devintaz, 2010). The contemporary environment features both progress and discord, as these fundamental liberties are at the center of union and worker issues (Northcentral University, n.d). Negotiation and collective bargaining have existed for decades, and given the conditions that gave birth to labor unions; their existence and purpose were justified. There is substantial debate over the value of labor unions and their continued existence in a globalized economy (Mellor \& Kath, 2011). Specifically, globalization brings new competitors from China, India, and Taiwan. In addition, these new global competitors enjoy higher profits and less expensive labor (Balanced Politics, n.d.).

In addition, the financial crisis and the weakening of the trade unions are consequences of a shift from one social and economic system to another (Salenko \& Grunt, 2001). With rising pressures from globalization and the financial crisis, governments worldwide are taking measures to reduce costs and increase profits (Mellor \& Kath, 2011; Salenko \& Grunt, 2001). The aforementioned conditions led to an attack on public-sector unions. As a result, "The attack on public sector unions had been underway for years in such states as Indiana" (Luce, 2012, p. 67). In addition, other states have opposed unions. For example, in 2005, the governor of Indiana rescinded state workers' right to collective bargaining. In Massachusetts, the right of government unions to bargain over medical insurance was rescinded, and in New York, political campaigns were led against unions (Luce, 2012). The decline of unions in the U.S. over the past six decades has concerned many researchers.

While some oppose labor unions, others regard them as valuable, especially for the public sector. In addition, public sector collective bargaining can be preserved if labor law is tailored to economic conditions in a way that benefits all stakeholders (government, public service workers, and tax payers). The researcher's intent is to review the background of public-sector labor relations, conduct an integrative review of the literature relevant to the challenges facing public-sector labor relations, and suggest recommendations for practitioners and future research that have both practical and scholarly value.

\section{Background}

Adler (2006) described the historical period that marked the birth of unions:

The framers of the U.S. Constitution and the interests they represented may have wanted to 'form a more perfect union,' but that desire did not extend to organizations of workers and skilled trade associations. As the new country began to grow, it saw the rise of merchant capitalist and the factory system. Workers sought to protect their earning power and their marketable skills by forming worker associations, mechanic societies, and fledgling unions of skilled craft workers. (p. 312) 
As originally written, the Constitution made no mention of labor unions. Therefore, when early workers formulated the notion of organizing to protect their earning power and marketable skills, employers regarded this as a threat to their business and profits. It was no surprise that employers retaliated because they regarded unionization as a potential problem for business. The Laws forbidding the restraint of trade were used to weaken and erode early unions. In addition, workers organized because they were opposed to overtime, marginal pay, a loss of self-governance, and unsafe working conditions (Adler, 2006).

As a result, workers joined unions, went on strikes, and struggled against management. In kind, management made use of every available method to pacify developing labor unions while supporting a legal system resistant to labor unions. Fast-paced manufacturing and the economic development in the U.S. during the mid-1860s led to the birth of national unions. In 1886, the National Labor Union (NLU) of skilled craft unions was formed. The NLU advocated increased wages, the establishment of an eight-hour workday, demanded equal-rights legislation for minorities, and women and sought to reform the country's monetary policy (Adler, 2006).

Before unions emerged, tradesmen refused to work and unlawfully encouraged others to do the same. In this way tradesmen tried to create better conditions. Apprentice shoemakers stood trial in 1806 and were convicted of criminal conspiracy. The aforementioned conviction established a legal precedent that stood until 1842, when the Massachusetts Supreme Court overturned the principle of criminal conspiracy (U.S. History, n.d.). Although early unions only existed for brief periods, the movements they represented set the stage for union organizing in the labor force. Union representation has led to many of the forms of compensation that employees currently receive (U.S. History, n.d.).

As mentioned above, as union density declined in the private-sector, public-sector unionization increased (Masters, Albright, \& Gibney 2010; Devintaz, 2010). Moreover, government-union relations underwent a 180-degree turn and deteriorated rapidly during the George W. Bush Administration (Masters, et al., 2010). In addition, globalization has brought an increased focus on the notion that the right to work is a human right. In summary, past abuses on the part of employers and their opposition to freedom of association among their employees explain the development of unions (Dawkins, 2012).

\section{Review of the Literature}

The purpose of the study was to explore the challenges facing the relationship between government and labor. Unfortunately, there is a dearth of research in the field of government-labor relations (Riccucci, 2011). The topics for the literature review included: issues in public-sector labor relations, collective bargaining, public perceptions of labor unions, public- and private-sector negotiations, and the impact of social environment on negotiations. The aforementioned themes provided the necessary background and current results that contributed to the analysis. The literature review was useful for integrating and synthesizing the most important works and studies on the topic, issues, purpose, and relevant analysis. 
In essence, the review of relevant professional and scientific works refined the subject considered, the objectives of and motivation for the study, and sharpened the focus of the analysis. The literature review verified the existence of a problem described by Riccucci (2011), which warranted further research. Multiple sources were consulted to locate current and relevant literature. Some contributions were found using the Northcentral University (NCU) Library resources system. Google ${ }^{\circledR}$ and Google Scholar ${ }^{\circledR}$ provided additional material and access to peer-reviewed material not accessible on NCU's library database. An external database, The Public Manager ${ }^{\circledR}$ provided access to peer-reviewed articles related to the federal government.

\subsection{Issues in Government Labor Relations}

"In the complex field of public sector labor-management relations many authors agree that government labor-management relationships are unique when compared to the relationship between labor and management in the private sector" (Imundo, 1973, p. 810). The aforementioned quote highlights a critical point connected to several issues pertaining to public-sector labor relations. Specifically, the sovereignty doctrine (the rights of the state) is the catalyst for several issues in government labor-management relations. The sovereignty doctrine is comparable to the issue of management's rights in the private sector. In addition, the sovereignty doctrine dictates that only the government (as employer) is permitted to establish the terms and conditions of employment (Imundo, 1973). The issues in public-sector labor relations include collective bargaining (Condrey, Facer, \& Llorens, 2012; Devinatz, 2012; Imundo, 1973; Kreisberg, 2004), public perceptions of public-sector labor unions (Bennett \& Masters, 2003; Devinatz, 2012; Givan \& Hipp, 2012), public- and private-sector negotiations (Imundo, 1973), and the impact of the environment on negotiations (Anderson \& Thompson, 2004; Kopelman, Rosette, \& Thompson, 2006).

\subsubsection{Collective Bargaining}

During the 1930s and 1940s, substantial conflicts emerged between unions and employers regarding the legality of forming a union and the scope of negotiations. Once unions were organized, labor laws were passed to legalize this organizing, collective bargaining agreements, and management's rights. Thereafter, changes in labor law, the National Labor Review Board, and court interpretations of the law increased union power and broadened the scope of negotiable issues in private-sector collective bargaining. However, the scope of negotiable issues in the private-sector is typically broader than that in government. Specifically, in the private sector, the law is designed to level the playing field by making the two parties equals. In contrast, in the public sector, the sovereignty doctrine prevents labor and management from bargaining as equals. For example, two states, Alabama and North Carolina, have laws that do not allow public workers to unionize for the purpose of collective bargaining (Imundo, 1973).

The sovereignty doctrine (the rights of the state) is the catalyst for several problems in public sector labor-management relations. From a different perspective, the sovereignty doctrine is 
similar to the issue of management's rights in the private sector. More important, government employees are limited in their attempt to collectively bargain with their employer because their salaries come from taxes, not profits. If government employees were allowed to bargain collectively, tax increases would follow, which would cause conflicts with organized pressure groups outside the government that pursue tax reduction as their primary aim. In contrast, private sector firms have three options for absorbing increased labor costs: raising prices; increasing efficiency; or reducing profits (Imundo, 1973).

As mentioned above, the government is limited in meeting increased labor costs of public workers because doing so would necessitate raising taxes. In addition, private firms find it easier to increase the efficiency of goods production than the government because the government produces services. Finally, the government does not generate profits and therefore cannot reduce profits as defined by accounting practices (Imundo, 1973). However, there seems to be a means of circumventing the sovereignty doctrine: “. . . this battle for survival will not be won by public sector unions fighting on their own but requires that they seek allies in what may very well turn out to be a life or death struggle" (Devinatz, 2012, p. 17). The aforementioned quote touches on why public sector unions are in a better position to create alliances to further their goals than private sector labor unions. The public workers' movements differ from private sector labor movements with respect to their demands, resources, and historical roles (Devinatz, 2012).

Specifically, public sector unions are obligated to express their demands as public policy that would be in the public interest. Private sector unions organize within and against labor markets; their objective is to remove wages from competition by establishing alliances among comparable workers employed across multiple companies operating in a given labor market. In contrast, public sector unions disregard the labor market and focus on creating coalitions to influence policy in a single public agency; workers'prospects for exercising power lie in the use of political-organizational resources such as legal rights, organizational status, and established procedures. Specifically, the power of public employees comes from their ability to articulate demands consistent with the public interest (Devintaz, 2012).

\subsubsection{Public Perception of Labor Unions}

Since the financial crisis of 2008, public sector unions have come under increasing attack. The Great Recession of 2007 through 2009 followed with elevated levels of unemployment exacerbated by unrestrained government spending. Several articles in the news media during this period accused government unions of contributing to excessive spending. The first set of attacks on government unions began in the 1970s, which coincided with a financial crisis, elevated inflation, and the dismantling of the New Deal welfare state. In addition, the public called for tax cuts, reductions in the size of government, and easing tax burdens on taxpayers. The first occasion when these demands were translated into action came when California voters passed Proposition 13 in 1978, immediately denying the state approximately $\$ 7$ billion in revenue; property taxes were rolled back to one percent of market value, and the proposition restricted assessment increases to two percent annually unless the house was sold. As a result, such legislation turned taxpayers against government workers and against one 
another (Devinatz, 2012).

However, the anti-tax revolts of the late 1970s not only sought to reduce the alleged excesses of big government, but were also used by union opponents to impede the prospering public employee union movement. Specifically, Howard Jarvis, the champion of Proposition 13, announced to voters that public sector unions were "Trying to run the country" (Devinatz, 2012, p. 8) but would not be permitted to do so. Following Howard Jarvis' announcement, in 1976, public sector labor championed the passage of a federal public sector bargaining law, the National Public Employee Relations Act, which was soundly defeated, began the assaults on public sector unions. In addition, in 1975 approximately 76,000 sanitation workers went on strike to protest layoffs during the city's budget crisis. Pennsylvania state employees, who were also union members, walked out when their demand for a 10 percent wage increase was rejected (Devinatz, 2012).

The aforementioned events resulted in a majority of Democratic politicians beginning to perceive that public-sector labor was scheming to obtain control of the government through editorials in major newspapers such as the New York Times, the Philadelphia Inquirer, and the Seattle Times. In addition, the assaults on organized public labor noted above provided the necessary ammunition and emboldened the Public Service Research Council (PSRC), an organization formed in 1973 by supporters of anti-union employment legislation, with the goal of confronting the rapid growth in public worker unionism. The PSRC's goal was to dismantle public sector collective bargaining, as politicians believed that its continued existence would enable unions to control government decision making. After the 9/11 attacks, public sector unions were perceived as a threat to combating terrorism within the nations' borders, and the Bush Administration sought to deny collective bargaining rights to those employed by the new Department of Homeland Security (Devinatz, 2012).

In addition, given the issues continuing to plague public education, teachers' unions were regarded as an obstacle to implementing education reform and continually blamed for refusing to align educator learning outcomes to student academic performance and their resistance to charter schools (Devinatz, 2012). There is consensus in the literature regarding to politicians' efforts to blame public-sector unions for the states' insolvency. Specifically, critics argued that public-sector unions were the main party responsible for imposing large government deficits by demanding and obtaining large salaries and pensions through collective bargaining (Devintaz, 2012; Walters, 2010).

\subsubsection{Public- and Private-Sector Negotiations}

In the complex field of government labor-management relationships, most of the literature agrees that government labor-management relationships are different from those in the public- and private-sector. Others have maintained that no real differences exist between labor-management relations in the public- and private-sectors. However, an examination of federal executive orders and state statutes demonstrates that, in certain respects, meaningful comparisons with the private sector can be developed. In the private sector, labor law is written to level the playing field. However, in government, the sovereignty doctrine makes bargaining as equals impossible. Two states, Alabama and North Carolina, have statutes 
that forbid public employees from joining unions for the purposes of collective bargaining (Imundo, 1973).

By late 1970, eight states had not given public employee unions the right to bargain collectively. As mentioned above, the sovereignty doctrine (the rights of the state) is at the forefront of many of the problems in government labor-management relations. In certain respects, the sovereignty doctrine is comparable to the issue of management's rights in the private sector. With respect to the governments' relationship with its employees, theoretically, the application of the sovereignty doctrine implies that only the government, as the employer, is permitted to establish the terms and conditions of employment. The literature agrees that government employees are restricted in their attempts to collectively bargain with their employer because their salaries come from taxes, not profits. What would be regarded as gains for private-sector unions, would have negative impacts on the public for public-sector unions. For example, if government employees were allowed to bargain collectively, then tax increases would follow (Imundo, 1973).

In addition, public-sector negotiations are limited by legislation and require public employees to behave differently than private-sector unions. As mentioned above, public-sector unions must express their demands as public policy that would be in the public interest. Private-sector unions organize within and against labor markets; their objective is to remove wages from competition by establishing alliances among comparable workers employed in numerous companies operating in a given labor market. In contrast, public sector unions disregard the labor market and focus on creating coalitions to influence policy within a public agency. Public-sector workers' prospects for exerting power lie in the use of political-organizational resources such as legal rights, organizational status, and established procedures. Specifically, public workers' power derives from their ability to align their demands with the public interest (Devintaz, 2012). There is a consensus in the literature that private-sector negotiations are much broader than private-sector negotiations, which are constrained by legal limitations due to the potential consequences such negotiations have for the public (American tax payers).

\subsubsection{Impact of Social Environment on Negotiations}

The importance of a cooperative relationship between union and management that improves efficiency and the quality of working life was reflected in the enactment of the Labor-Management Cooperation Act of 1978. This act was designed to encourage cooperative union-management ventures to improve communication, explore fresh and creative joint methods for achieving organizational effectiveness, permit greater employee participation, and eliminate economic conditions that limit the competitive ability and economic growth of a plant, region, or industry. Schuster (1983) selected ten sites owned by firms with active with labor-management productivity programs. At one particular site, a Scanlon and Rucker plan was implemented as a last effort to save the firm from a corporate decision to close the site in 1971 for financial reasons (Schuster, 1983).

Through hastily arranged negotiations, terms were reached under which management would continue to operate the plant. Two of these terms were union pledges to affect a substantial 
increase in productivity and end negotiated work standards. In return, and as a result of recommendations from Scanlon committees, management agreed to contract language that precluded worker layoffs. In the six months prior to the implementation of the plan, approximately 20 percent of the bargaining unit's members had been laid off, but employment later stabilized. The firm experienced a marked increase in productivity, along with a further reduction in employment. In subsequent years, the Scanlon Plan continued to be successful within the firm, and ten years following its initiation, the program remained active (Schuster, 1983).

The literature seems to suggest that affective processes may be beneficial in producing collaboration and mutually beneficial bargaining. In addition, the application of power and the experience of affect are the most basic aspects of social interaction. As a result, the literature on negotiating behavior has begun to examine the outcomes of the application of power on negotiations. Interestingly, however, power and affect in negotiation have been studied separately in the literature, when in fact, they are closely related in social interactions. Variations in power can alienate negotiating parties, increasing the difficulty of arriving at mutually beneficial agreements (Anderson \& Thompson, 2004).

In addition, the literature has emphasized the role emotions play at the negotiating table and noted how the purposeful use of emotional display can be strategically employed by a negotiator. However, there are potential ethical concerns that must be addressed regarding the purposeful display of emotions, which may be regarded as dishonest or manipulative. The recognition of emotions displayed in social settings is known to be a developmentally adaptive characteristic of human behavior. Specifically, the findings of two studies show that negotiators' with more power can more effectively deploy positive effect to influence bargaining outcomes than negotiators' who are not as powerful. The positive effect of negotiators' with greater power was the best predictor of the trust that emerged during the negotiation and it was the best, and only, predictor of mutually beneficial outcomes (Kopelman, Rosette, \& Thompson, 2006).

The main hypothesis in Kopelman, Rosette, \& Thompson's (2006) study was that when negotiators' possessing greater power use positive effect, this behavior would be more likely to predict the likelihood that a mutually beneficial agreement would be reached than attempts by negotiators who were not as powerful. Figure 1 illustrates this effect. As shown, the probability of reaching an integrative agreement rather than an impasse increased when the more powerful negotiator was more positively affective. In addition, figure 1 indicates that less powerful negotiators' use of positive affect had no effect on the outcome. It is interesting that the positive affect of both parties was equally vital in predicting whether dyads reached mutually beneficial, rather than non-beneficial agreements (Anderson \& Thompson, 2004).

This result could have been due to the small sample size used to compare integrative and non-integrative agreements $(\mathrm{N}=26)$ or the different factors that contribute to integrative and non-integrative agreements. Integrative agreements required more than the development of mutual trust; they also required an ability to think creatively and devise solutions that were 


\section{Macrothink}

Journal of Public Administration and Governance

ISSN 2161-7104

2013, Vol. 3, No. 4

not immediately apparent. Thus, it is possible that both powerful and less powerful negotiators' positive affect might have facilitated creative thinking and contributed to reaching an integrative or non-integrative agreement (Anderson \& Thompson, 2004).

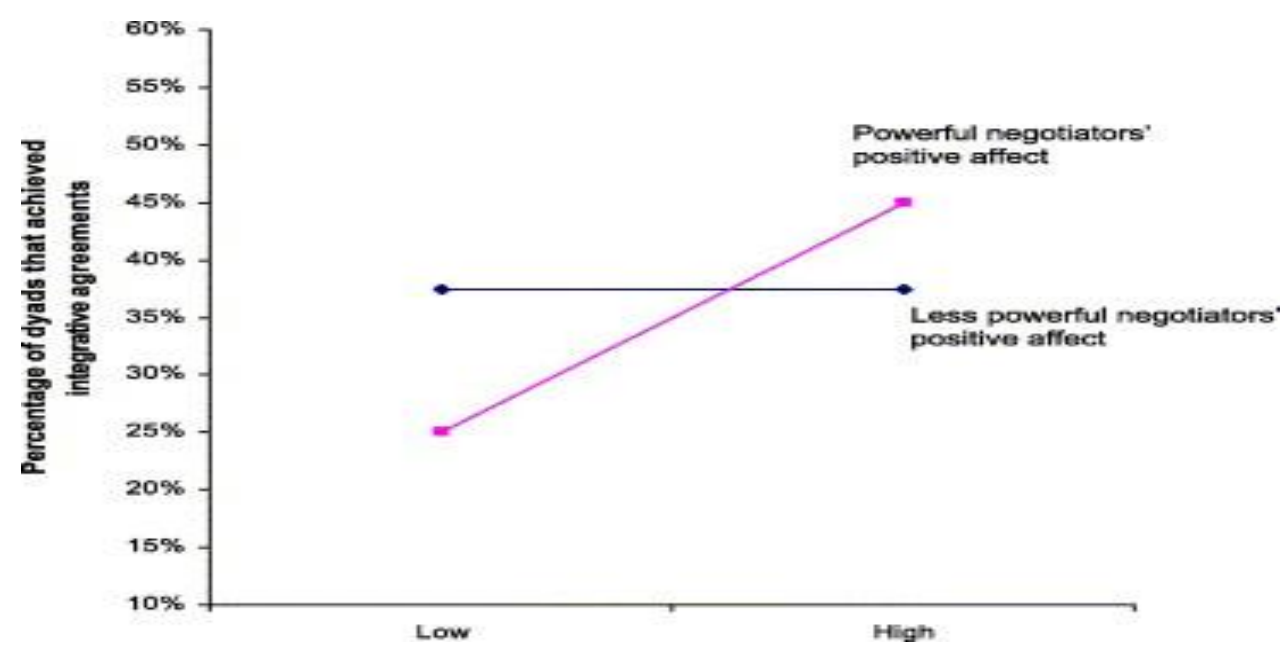

Figure 1. Study 1: The probability of reaching an integrative agreement rather than an impasse increased when powerful individuals were more positively affective.

Source: Adapted from Anderson and Thompson (2004, p. 130). The model deviance was 31.29

Social psychological research emphasizes on the benefits of positive affect, while another perspective argues that in contrast to positive emotional displays, negotiators who display negative emotion can be extremely effective at the bargaining table. By ranting and raving and being unpleasant, a negotiator can shift the negotiation in his favor and convince the other party to succumb to his demands. The good-cop bad-cop strategy leverages the effect of negative emotions. Criminal investigators capitalize on the perceptual contrast between a friendly negotiator who establishes rapport through amplified displays of compassion and is only able to extract concessions because of the demands previously made by a negative co-conspirator. Specifically, a finding suggests that when two individuals negotiated as a team and sequentially shifted between cooperative and competitive strategies (which may be regarded as positive and negative approaches), greater concessions were made by the other party and the distance between offers was reduced (Kopelman, et al., 2006).

However, in some settings, a display of negative emotion may be detrimental to the negotiation process and outcomes. For instance, insulting offers that generate negative affect are rejected in ultimatum bargaining settings. In addition, it was found that negotiators who experienced high anger and low compassion achieved lower joint gains and had a reduced desire to cooperate in the future. Thus, a strategic display of negative emotion in a dispute setting may lead to a conflict spiral that is difficult to break (Kopelman, et al., 2006). 


\section{Summary}

Multiple themes were presented in the literature review. The review included current and relevant, peer-reviewed, scholarly research aligned with the guiding concept of an integrative literature review relevant to the challenges facing government labor relations. The trends observed in the literature review included considerations on theoretical, suggestive, strategic, and preventive measures that when researched could aid in explaining and creating strategic approaches to the challenges facing government unions, government workers, government leaders, and taxpayers. The challenges facing government agencies are manifested through inflexible labor laws such as the sovereignty doctrine (the rights of the state), which is similar to the issue of management's rights. As mentioned above, the sovereignty doctrine makes it impossible for government unions to be equals of management and creates tension as a result (Imundo, 1973).

There is a consensus in the literature regarding the differences between private-sector unions and government unions. Specifically, there is a profit motive for private-sector businesses and therefore unions exercise bargaining rights to extract monetary gains from a firm's profits in the form of increased wages and benefits. In contrast, government unions are restricted from fully exercising their bargaining rights because negotiated increases in wages result in tax increases. In addition, the literature agrees that when the U.S. experiences a financial crisis or economic downturn government unions are attacked as the source of over spending, which is followed by anti-union activities to remove labor rights (Imundo, 1973).

The public perception of labor unions in the literature since the 2008 financial crisis continues to change as political leaders seek to shift the blame for negligent spending to potentially enhance their likelihood of reelection (Devinatz, 2012). The researcher has noted that the future strategy of government unions must include lobbying congress to enact a long-term collective bargaining law that is tailored to the needs of every stakeholder (congress, government unions, government workers, and tax payers). Specifically, such labor legislation should grant situation-based and limited monetary and non-monetary collective bargaining rights to government employees at all levels of government. Once labor legislation is rewritten, government unions will have a unique opportunity to strategically position themselves and better serve their members.

The literature on public- and private-sector negotiations diverge on several issues relating to unions and management being equals during negotiations, the profit motive, and serviceoriented production versus manufacturing. This divergence is evinced by trends in the literature illustrating periods in history when government unions were blamed for budget deficits (Imundo, 1973). One emerging trend in the literature is the growing problem of government leaders' inability to manage and balance the national budget. The issue of balancing a national budget is nothing new. However, the issue impacts government unions whenever a financial crisis is present. This issue regarding balancing the national budget and its impact on government unions is critical and further affects the analysis of challenges facing government labor relations. A second emerging trend within the literature is the use of influence by political leaders to change and shape public opinions of government unions. 
In addition, a political leader's use of power to strip government unions of collective bargaining rights and introduce anti-union legislation (Imundo, 1973) is another emerging trend in the literature that also contributes to my analysis.

The impact of environment on negotiations provides an interesting perspective and represents an essential element of social interactions. However, in the literature, studies have considered negotiator power and positive affect separately without realizing how the two could potentially impact the collective bargaining (Condrey, et al., 2012; Devinataz, 2012; Kreisberg, 2004) process and government labor relations (Imundo, 1973). The added benefits of pursuing future research that combines negotiator power and positive affect has the potential of contributing to the body of knowledge and filling a gap in the literature in the context of integrative bargaining outcomes. An emphasis on the willful display of emotions during negotiations is critical to facilitating win-win agreements (Anderson \& Thompson, 2004).

\section{Recommendations}

As mentioned above, "In the complex field of public sector labor-management relations many authors agree that government labor-management relationships are unique when compared to the relationship between labor and management in the private sector" (Imundo, 1973, p. 810). This quote lies at the center of my analysis. The literature revealed that the 'uniqueness' of public-sector labor-management relations lies in the nonprofit nature of government business. The main issue surmised from the literature is that when applied to private-sector business, collective bargaining is tied to monetary gains for labor in the form of increased wages and other forms of compensation such as pensions, bonuses, and annual wage increases (Imundo, 1973; Condrey, et al., 2012; Devintaz, 2012; Kreisberg, 2004). However, when collective bargaining is applied to public-sector business, it must be tailored to achieve proper alignment with tax payers' interest who are the major stakeholders in public-sector services.

Therefore, I recommend that human resource management and management practitioners lobby for collective bargaining legislation that is tailored and will not be repealed because it provides a win-win situation that satisfies not only taxpayers, but also Congress, public-sector employees, and public-sector unions. In addition, the researcher recommends future research into the impact of public-sector labor relations on inflation and the cost of living as implied by Walters (2010). Walters (2010) linked metro areas' levels of unionization to subsequent changes in a city's real median income and demonstrated that as unionization grew, the city grew poorer. Furthermore, the researcher recommends future research that combines negotiator power and positive affect that has the potential of contributing to the body of knowledge and filling a gap in the literature in the context of integrative bargaining outcomes (Anderson \& Thompson, 2004).

\section{Conclusion}

In summary, I reflect on the thesis of my analysis; although some oppose labor unions, others perceive their value, especially for the public sector. In addition, collective bargaining by government employees can be preserved if labor law is tailored to economic conditions in a way that benefits all stakeholders 
(government, public service workers, and tax payers). As mentioned above, government unionism emerged and increased as unionization declined in the private sector (Masters, Albright, \& Gibney 2010; Devintaz, 2010). Growth in public-sector unions was due to the enactment of union-friendly legislation. Specifically, federal labor-management relations experienced a complete 180-degree turn around when President Bush took office (Masters, et al., 2010). In addition, the sovereignty doctrine (the rights of the state) is the catalyst for several issues in public-sector labor-management relations. The sovereignty doctrine is comparable to the issue of management's rights in the private sector.

In addition, the sovereignty doctrine necessitates that the government, as the employer, alone can establish the terms and conditions of employment (Imundo, 1973). More importantly, government employees are limited in their ability to collectively bargain with their employer because their salaries come from taxes, not profits. If government employees were allowed to bargain collectively, tax increases would follow, which would generate conflicts with organized pressure groups outside the government with the main objective of reducing taxes. In contrast, private sector firms have three options to absorb increased labor costs: raising prices; increasing efficiency; or reducing profits (Imundo, 1973). The main issue surmised from the literature is that collective bargaining is tied to monetary gains for labor in the form of increased wages and other forms of compensation such as pensions, bonuses, and annual wage increases (Imundo, 1973; Condrey, et al., 2012; Devintaz, 2012; Kreisberg, 2004). For collective bargaining to be effective in the public sector, it must be tailored such that it is properly aligned with the interests of tax payers, who are the major stakeholders in public-sector services.

\section{Acknowledgement}

I want to thank my mentor at Northcentral University, Dr. Rayshad Holmes and Suzanne, Senior Editor of American Journal Experts for their review and insightful comments.

\section{References}

Adler, J. (2006). The past as prologue? A brief history of the labor movement in the United States. Public Personnel Management, 35(4), 311-329.

Anderson, C., \& Thompson, L. L. (2004). Affect from the top down: How powerful individuals' positive affect shapes negotiations. Organizational Behavior and Human Decision Processes, 95(2), 125-139. http://dx.doi.org/10.1016/j.obhdp.2004.05.002

Balanced Politics. (n.d.). Are labor unions a good thing? [Online] Available: http://www. balancedpolitics.org/unions.htm (June 20, 2013).

Condrey, S. E., Facer II, R. L., \& Llorens, J. J. (2012). Revitalize the federal workforce by strengthening four critical areas. Public Manager, 41(4), 62-65.

Dawkins, C. E. (2012). Labored Relations: Corporate citizenship, labor unions, and freedom of association. Business Ethics Quarterly, 22(3), 473-500. http://dx.doi.org/10.5840/ beq201222331

Devinatz, V. G. (2012). The attack on US public sector unionism in the age of austerity. Labor Law Journal, 63(1), 5-21. 


\section{Macrothink}

Journal of Public Administration and Governance

ISSN 2161-7104

2013, Vol. 3, No. 4

Devinatz, V. G. (2010). Does the change to win federation represent U.S. labor's third moment? Evidence from national labor relations board certification elections, 2003-2005. Employee Responsibilities and Rights Journal, 22(3), 161-173. http://dx.doi.org/10.1007/ s10672-009-9120-8

Imundo Jr., L. V. (1973). Some comparisons between public sector and private collective bargaining. Labor Law Journal, 24(12), 810-817. [Online] Available: http://ehis.ebscohost. com/eds/detail? vid=8\&sid=1bd09e49-c9c1-4799-8935-a748c45f3b39\%40sessionmgr110\& hid=6\&bdata=JnNpdGU9ZWRzLWxpdmU \%3d\#db=bth\&AN=5821536 (June 23, 2013).

Kopelman, S., Rosette, A. S., \& Thompson, L. (2006). The three faces of Eve: Strategic displays of positive, negative, and neutral emotions in negotiations. Organizational Behavior and Human Decision Processes, 99(1), 81-101. http://dx.doi.org/10.1016/j.obhdp.2005. 08.003

Luce, S. (2012). The good, the bad, and the ugly: A Labor Day assessment of the past year. New Labor Forum, 21(3), 67-73,126. [Online] Available: http://search.proquest.com.proxy1. ncu.edu/ docview/1039560173?accountid=28180

Masters, M. F., Albright, R. R., \& Gibney, R. (2010). The state of public sector unionism: Challenges and opportunities. Employee Responsibilities and Rights Journal, 22(3), 255-274. http://dx.doi.org/10.1007/s10672-010-9152-0

Mellor, S., \& Kath, L. M. (2011). Fear of reprisal for disclosing union interest: Assessing the effectiveness of perceived anti-unionism. Employee Responsibilities and Rights Journal, 23(2), 117-129. http://dx.doi.org/10.1007/s10672-010-9154-y

Northcentral University. (n.d.). Labor relations. [Online] Available: http://learners.ncu.edu/ syllabus/display_full.aspx?syllabus_id=28952 (December 23, 2013).

Salenko, V. a., \& Grunt, E. V. (2001). What today's trade union leader is like. Sociological Research, 40(6), 74. [Online] Available: http://ehis.ebscohost.com/ehost/detail?sid= e51606458309-4212-998f-928cf1d374b8\%40sessionmgr114\&vid=1\&hid=115\&bdata= JnNpdGU9ZWhvc3QtbG12ZQ\%3d\%3d\#db=bth\&AN=6298282 (December 23, 2013).

Schuster, M. (1983). The impact of union-management cooperation on productivity and employment. Industrial \& Labor Relations Review, 36(3), 415-430. [Online] Available: http://ehis.ebscohost.com/eds/pdfviewer/pdfviewer?vid=4\&sid=1bd09e49-c9c1-4799-8935a748c45f3b39\%40sessionmgr110\&hid=106

U.S. History. (n.d.). American labor movement. [Online]. Available: http://www.u-s-history. com/pages/h1678.html (June, 8, 2013).

Walters, S. J. K. (2010). Unions and the decline of U.S. cities. Cato Journal, 30(1), 117-135. [Online] Available: http://search.proquest.com.proxy1.ncu.edu/docview/195600282? accountid= $28180($ December 21, 2013). 


\section{Copyright Disclaimer}

Copyright reserved by the author(s).

This article is an open-access article distributed under the terms and conditions of the Creative Commons Attribution license (http://creativecommons.org/licenses/by/3.0/). 